\title{
Epidemiological and Pathological Study of Lung Cancer in Patients Referred to Ekbatan and Shahid Beheshti Hospitals in Hamadan during 2001 - 2016
}

\section{Mohammad Abbasi', Fahimeh Moradi², Farzaneh Esna-Ashari, ${ }^{3, *}$ Mohammad Ali Seifrabiei $^{3}$}

${ }^{1}$ Assistant Professor, Department of Internal Medicine, School of Medicine, Hamadan University of Medical Sciences, Hamadan, Iran

${ }^{2}$ Medical Student, Hamadan University of Medical Science, Hamadan, Iran

${ }^{3}$ Associate Professor, Department of Social Medicine, School of Medicine, Hamadan University of Medical Sciences, Hamadan, Iran

* Corresponding Author: Farzaneh Esna-Ashari, Department of Social Medicine, School of Medicine, Hamadan University of Medical Sciences, Hamadan, Iran. Email: esna_f@yahoo.com

\begin{tabular}{|c|c|}
\hline & Abstract \\
\hline $\begin{array}{l}\text { Received: } 03.08 .2018 \\
\text { Accepted: } 17.01 .2019\end{array}$ & $\begin{array}{l}\text { Background and Objective: Lung cancer is one of the most common types } \\
\text { of cancer and the main reason of cancer-caused mortality in Iran. The }\end{array}$ \\
\hline $\begin{array}{l}\text { How to Cite this Article: } \\
\text { Abbasi M, Moradi F, Esna- } \\
\text { Ashari F, Seifrabiei MA. Epide- } \\
\text { miological and Pathological } \\
\text { Study of Lung Cancer in } \\
\text { Patients Referred to Ekbatan and } \\
\text { Shahid Beheshti Hospitals in } \\
\text { Hamadan during } 2001-2016 \text {. } \\
\text { Avicenna J Clin Med. 2019; } \\
\text { 25(4): 236-243. DOI: 10.21859/ } \\
\text { ajcm.25.4.236 }\end{array}$ & $\begin{array}{l}\text { prevent the prevalence and incidence of cancer. } \\
\text { Materials and Methods: This comparative descriptive study was } \\
\text { conducted on patients with lung cancer referring to Ekbatan and Shahid } \\
\text { Beheshti Hospitals during 2001-2016. Risk factors as well as clinical and } \\
\text { demographic data were collected from medical records. } \\
\text { Results: The mean age of the patients was } 61.11 \pm 12.23 \text { years and } 166 \\
\text { patients ( } 83 \%) \text { were male. A total number of } 120(66.7 \%) \text { patients lived in } \\
\text { urban areas. The frequency of patients who had a positive history for } \\
\text { consumption of opioid, industrial drugs, cigarette, and hookah were } 2 \%, 0 \% \text {, } \\
42.2 \% \text {, and } 1 \% \text {, respectively. The most common symptoms were cough and } \\
\text { dyspnea. The time interval between the appearance of clinical signs and } \\
\text { diagnosis was } 5.32 \text { months. The most common paraneoplastic symptom was } \\
\text { bone pain ( } 45.5 \%) \text { and the most frequent pathologic form was squamous } \\
\text { cell carcinoma (33.5\%). The right upper lobe (27.5\%) and left upper lobe } \\
\text { (23.5\%) were the most common lobes. } \\
\text { Conclusion: Since the time interval between clinical signs and diagnosis was } \\
\text { long and squamous cell carcinoma was the most common type of cancer, it } \\
\text { is important to control risk factors, specifically smoking, to prevent cancer. } \\
\text { Kevwords: Epidemiology. Lung Neoplasms. Pathology }\end{array}$ \\
\hline
\end{tabular}




\title{
بررسى إيدميولوزيك و پاتولوزيك سرطان ريه در مراجعه كنندكان به بيمارستان

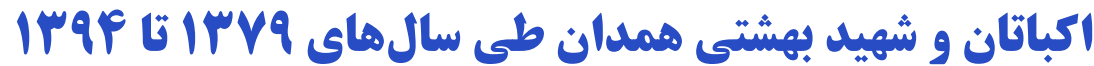

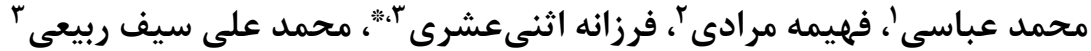 \\ ' ' استاديار، كروه بيمارى هاى داخلى (هماتولوزى و انكولوزى)، دانشكده يزشكى، دانشكاه علوم يزشكى همدان، همدان، ايران

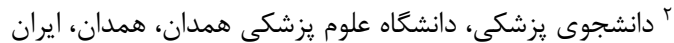

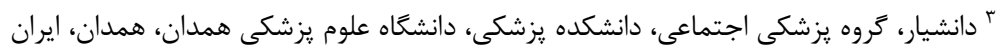 \\ * نويسنده مسئول: فرزانه اثنى عشرى، كروه يزشكى اجتماعى، دانشكده يزشكى، دانشكاه علوم يزشكى همدان، همدان، ايران. \\ ايميل: esna_f@yahoo.com
}

\begin{tabular}{|c|c|}
\hline جكيده & \\
\hline سابقه و هدف: سرطان ريه يكى از شايعترين سرطانها و مهمترين عامل مرَى و مير ناشى از آنها مى باشد. & 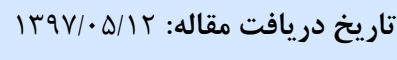 \\
\hline اطلاع از ويزگكىهاى ياتولوزيك و إييدميولوزيك سرطان ريه كه هدف اين مطالعه است، مىتواند مبنايى جهت & 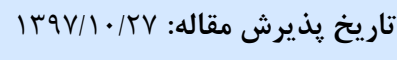 \\
\hline تصميمَّيرى در زمينه پِيشَيرى از سرطان باشد. & \\
\hline 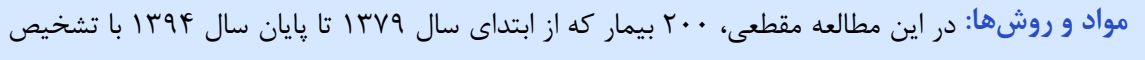 & ق سر براى داسله عوم \\
\hline سرطان ريه به بيمارستان اكباتان و شهيد بهشتى همدان مراجعه كرده بودند، ارزيابى شدند. شايان ذكر است & 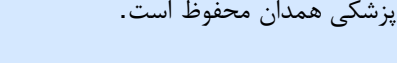 \\
\hline كه اطلاعات دموكرافيك، سـابقه مواجهه با عوامل خطر و يافته هاى بالينى و ياراكلينيكى از برونده بيماران & \\
\hline 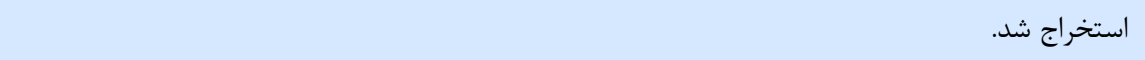 & \\
\hline 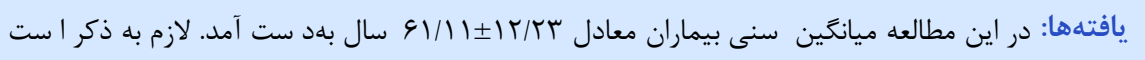 & \\
\hline 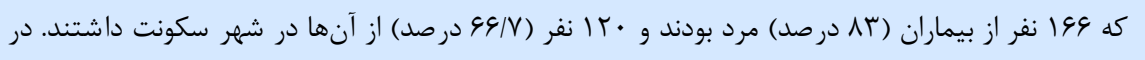 & \\
\hline 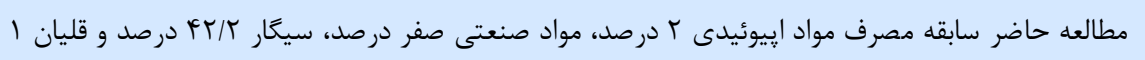 & \\
\hline در صد كزارش شد. شايعترين علامت بالينى نيز سرفه و تنكى نفس بود. بايد خاطرنشان ساخت كه فاصله & \\
\hline 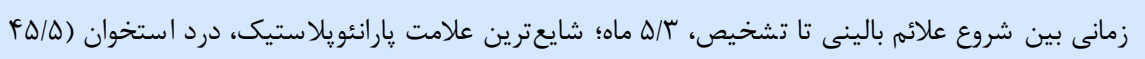 & \\
\hline 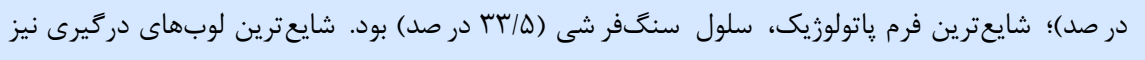 & \\
\hline بهترتيب عبارت بودند از: (Right Upper Lobe) RUL (هV/ه درصــد و و (Left Upper Lobe) LUL & \\
\hline 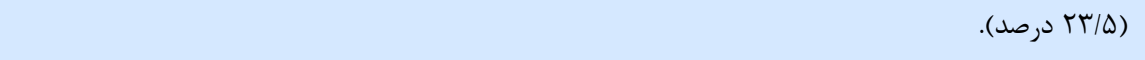 & \\
\hline نتيجه كَيرى: براساس نتايج مطالعه حاضر مشخص شد كه فاصله زمانى بين شروع علائم بالينى تا تشخيص & \\
\hline بيمارى نسبتاً زياد است. همجنين، مشاهده كَرديد كه سرطان سلول سنَّفرشى داراى بيشترين فراوانى & \\
\hline مىباشد كه اين امر نشان از اهميت كنترل عوامل خطر بهويزه سيكار در اين بيماران دارد. & \\
\hline وازگًان كليدى: آسيبشناسى، سرطان ريه، همه كيرىشناسى & \\
\hline
\end{tabular}

يك بيمارى نادر تبديل به يكى از كشندهترين سرطانها در

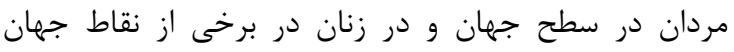

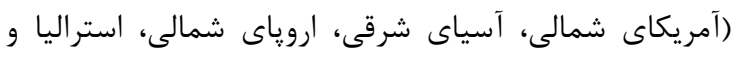

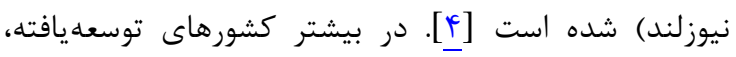

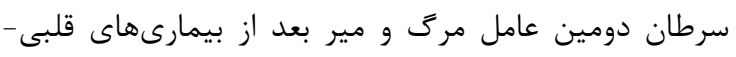

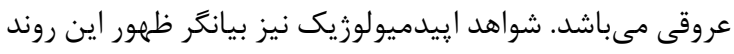

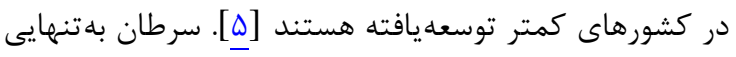
منجر به مرى ساليانه ب....
سرطان ريه يكى از شايعترين سرطانها در ايالات متحده

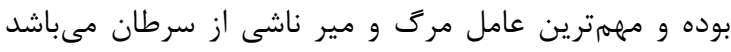

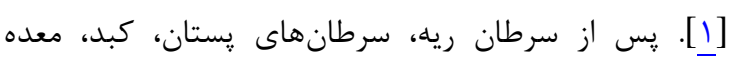

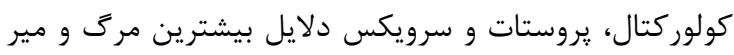

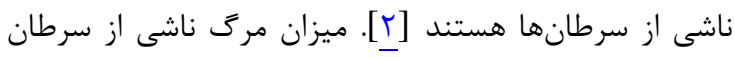

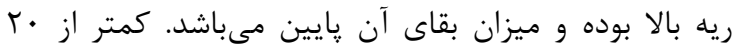

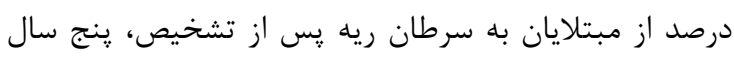

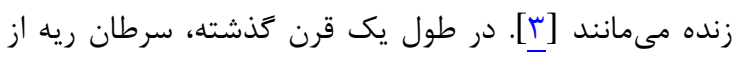




\section{مواد و روشها}

بلهنظور انجام مطالعه مقطعى حاضر، يرونده يزشكى

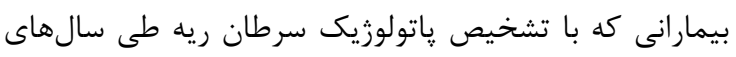

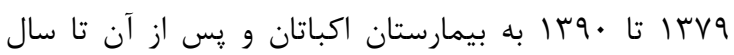

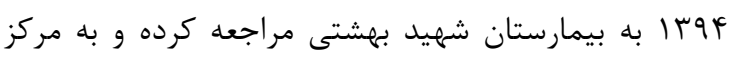

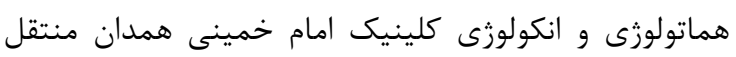

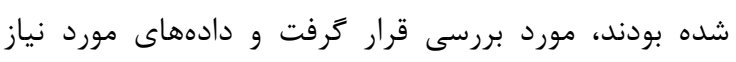

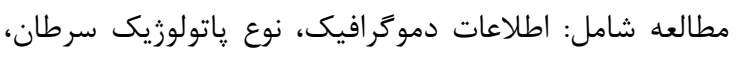

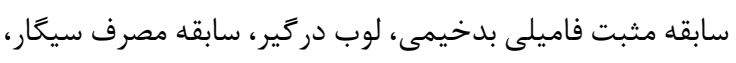

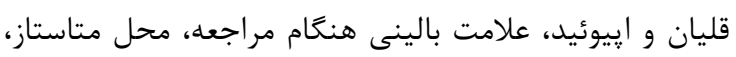

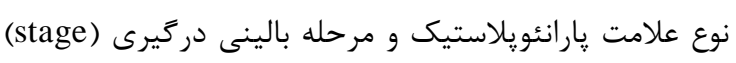

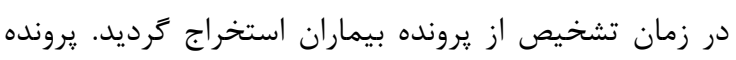

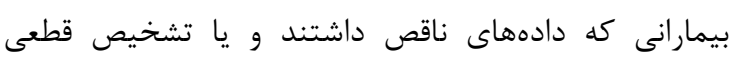

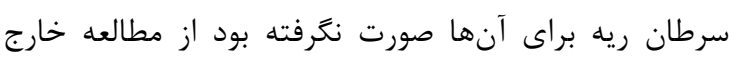

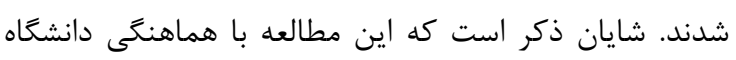

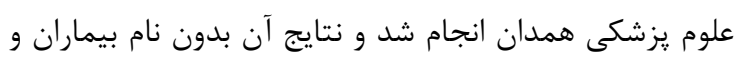
بdصورت كلى منتشر گرديد.

بهمنظور دستيابى به اهداف مطالعه، آمار توصيفى مورد استفاده قرار گرفت، براى مقايسه بين متغيرهاى كيفى از آزمون

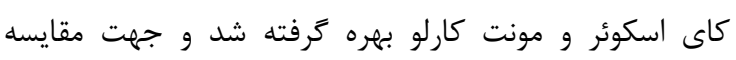

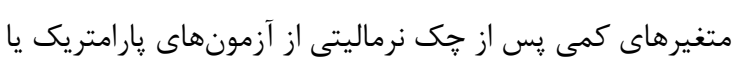

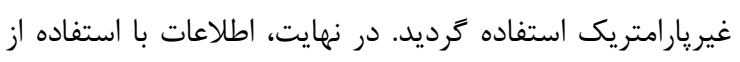
نرمافزار SPSS 16 تجزيه و تحليل شدند.

يافته ها

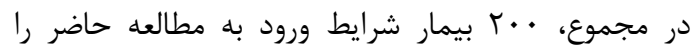

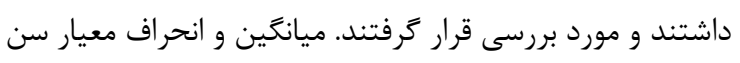

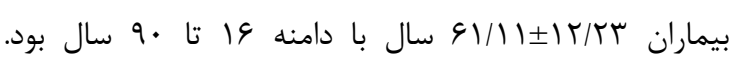

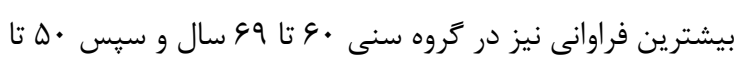
Q9 سال مشاهده كرديد (شكل (1).

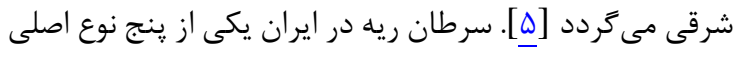

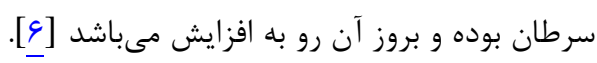

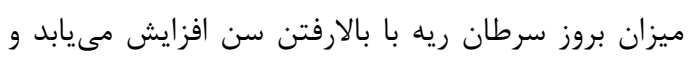

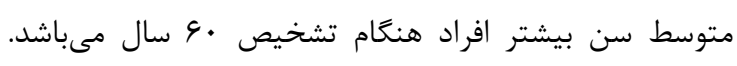

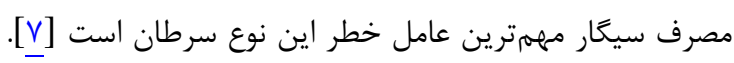

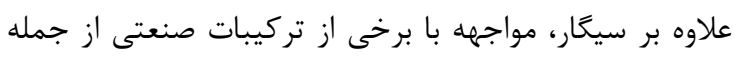

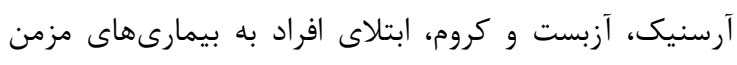

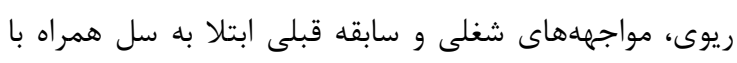

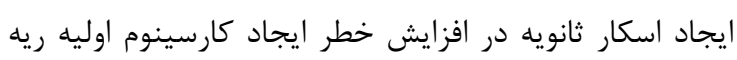

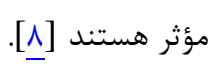

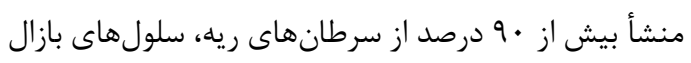

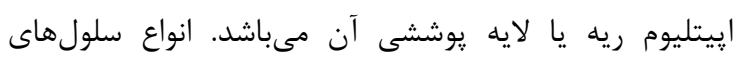

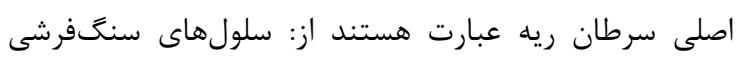
(SCC: Squamous Cell Carcinoma) SCLC: Small (Adenocarcinoma) NSCLC: Large و سلولهاى بزرى (Cell Lung Cancer Cell Lung Cancer

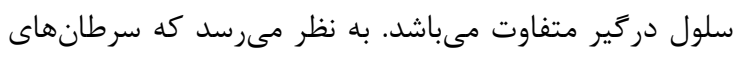

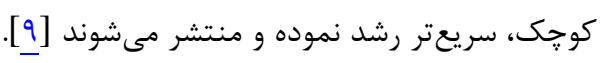

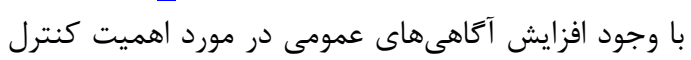

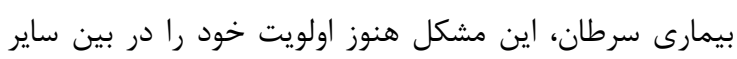

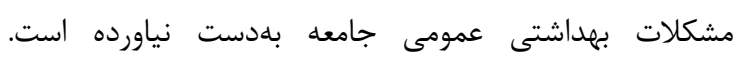

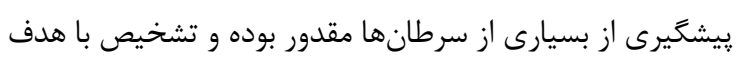

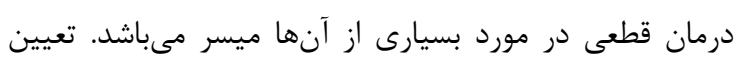

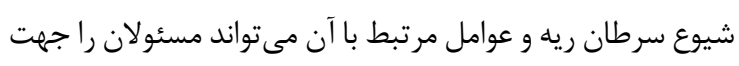

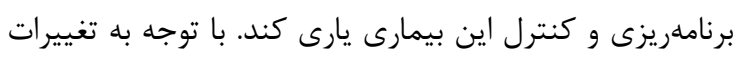

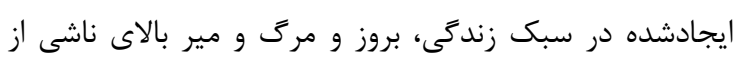

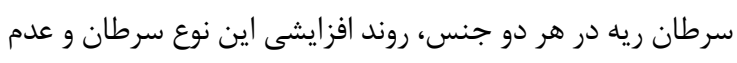

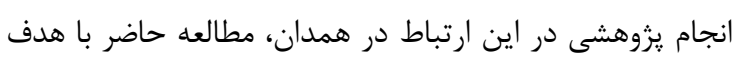

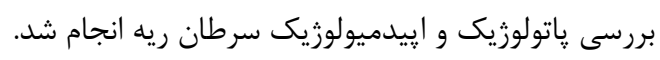

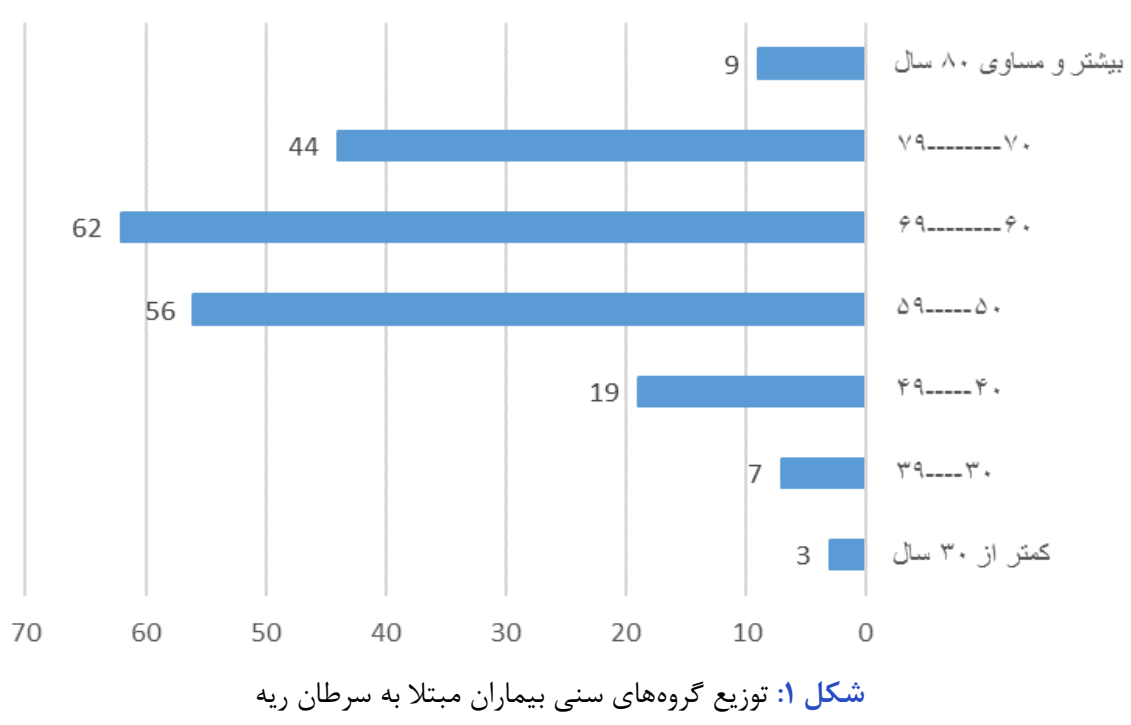


ماه بود و بيمارى در بيشتر بيماران طى كمتر از سه ماه تشخيص (حده اده داده شده بود (جدول (1).

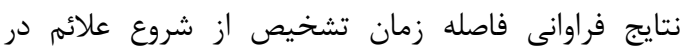
مبتلايان به سرطان در شكل r و فراوانى نسبى مبتلايان به رسه

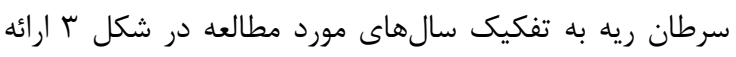
شده است. شايعترين علائم بالينى در مبتلايان به سرطان ريه عبارت

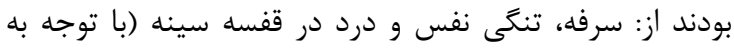

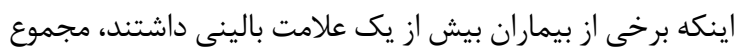

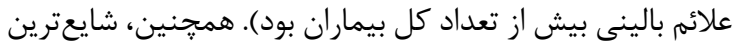

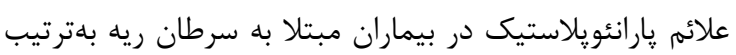

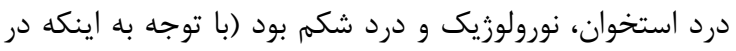

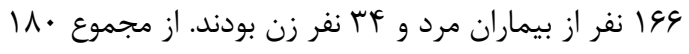

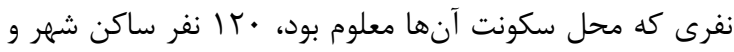

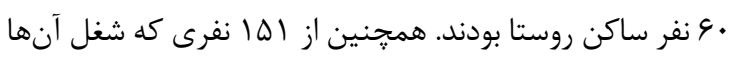

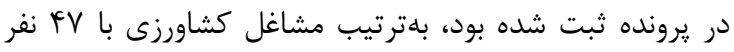

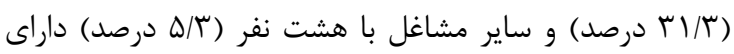

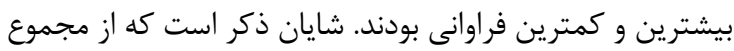

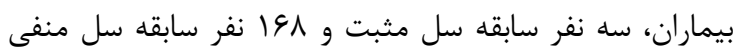

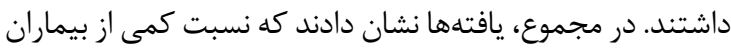

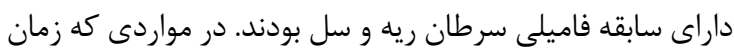

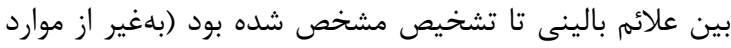

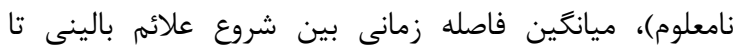

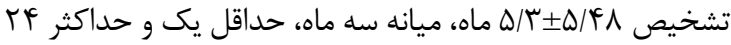

جدول ا: مشخصات دمو گرافيك و سابقه بيمارى مبتلايان به سرطان ريه

\begin{tabular}{|c|c|c|c|}
\hline درصد & غراوانى & & متغير \\
\hline$\wedge \mu$ & 199 & مرد & جنسيت \\
\hline IV & ry & زن & \\
\hline $99 / \mathrm{V}$ & ir. & 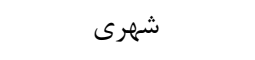 & محل سكونت (•11 نفر) \\
\hline 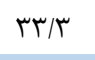 & c. & 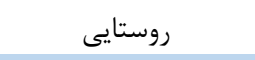 & \\
\hline$r M / l$ & FV & كشاورز & \\
\hline$r 9 / 1$ & fr & 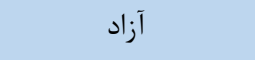 & \\
\hline $19 / 4$ & rq & 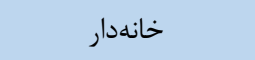 & شغل (اها نفر) \\
\hline $10 / T$ & r & كارمند & \\
\hline$\Delta / \Gamma$ & $\wedge$ & 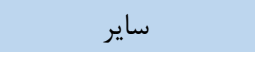 & \\
\hline $1 / 0$ & $r$ & بله & \\
\hline $1 / 0$ & r & خير & سابقه فاميلى \\
\hline १७ & 194 & 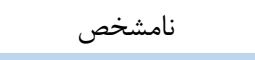 & \\
\hline $1 / 0$ & r & بله & \\
\hline NF & 191 & 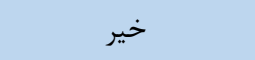 & سابقه سل \\
\hline $\mid F / \Delta$ & rq & 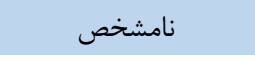 & \\
\hline \multicolumn{2}{|c|}{ GI/IIIIT/K } & ميانگين土انحراف معيار & سن (سال) \\
\hline \multicolumn{2}{|c|}{$\Delta / r T \pm \Delta / F \wedge$} & ميانخين土|نحراف معيار & زمان تشخيص از شروع علائم (ماه) \\
\hline
\end{tabular}

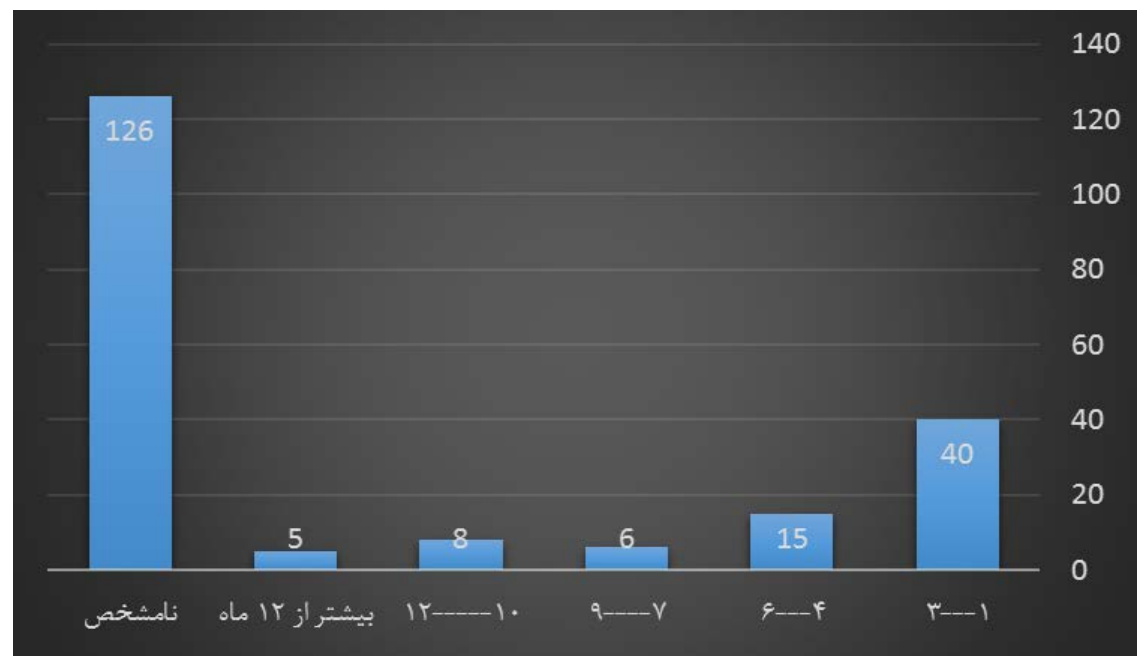

شكل r: توزيع فراوانى فاصله زمان تشخيص از شروع علائم (ماه) در مبتلايان به سرطان ريه 


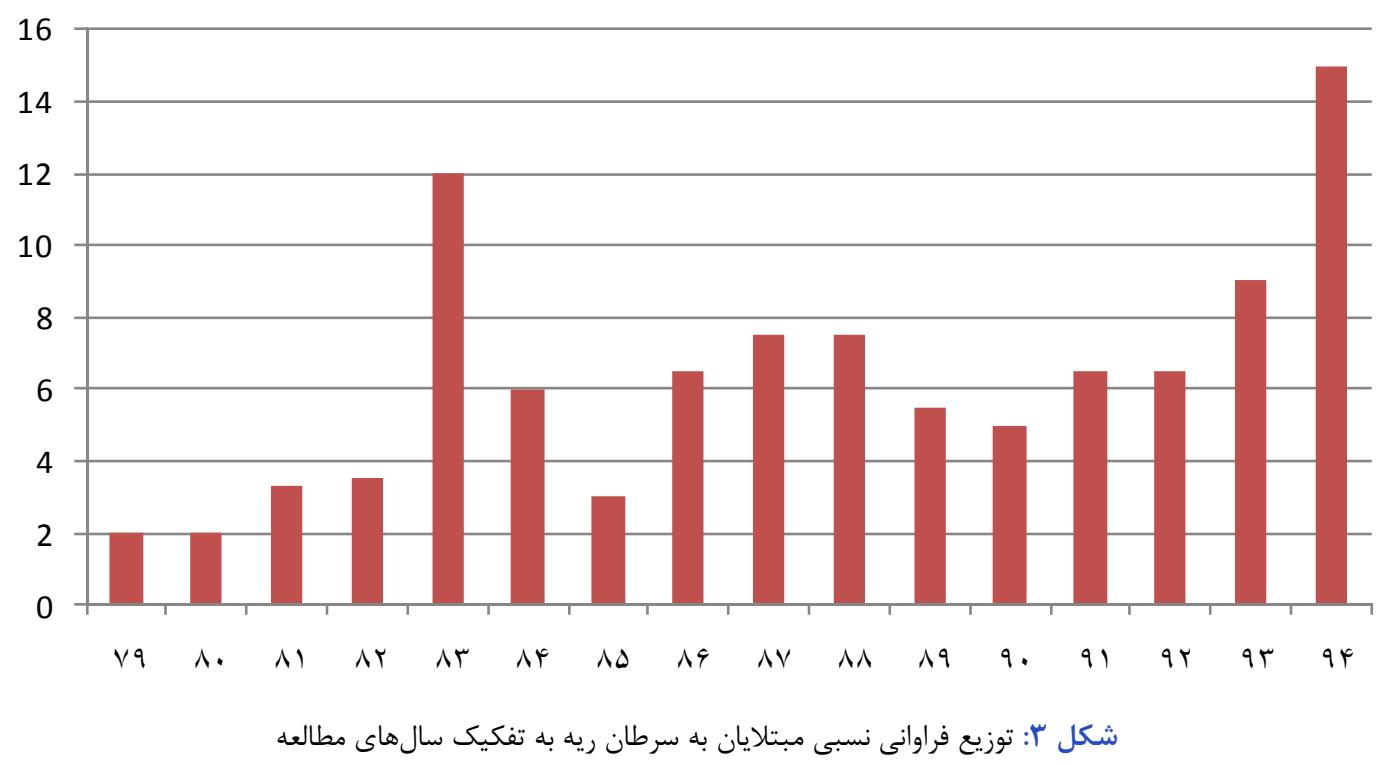

شايعترين فرم گِاتولوزيك سرطان ريه عبارت بودند از:

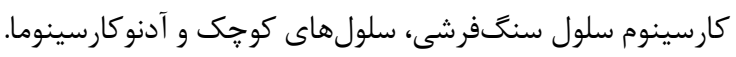

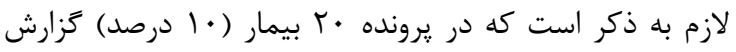

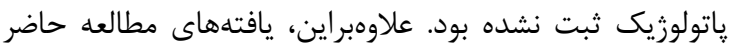

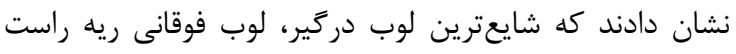

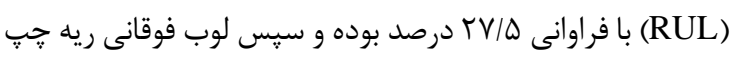

برخى از بيماران بيش از يك علامت يارانئويلاستيك وجود

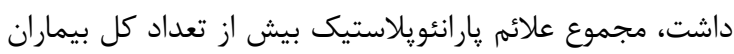

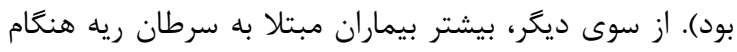

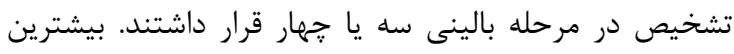

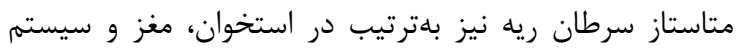

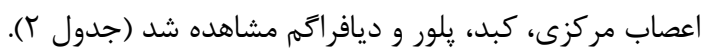

جدول r: فراوانى علائم بالينى، علائم پارانئويلاستيك، مرحله بالينى و محل متاستاز تومور

\begin{tabular}{|c|c|c|c|}
\hline درصد & 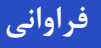 & & 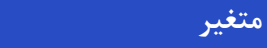 \\
\hline$F \Delta / \Delta$ & 91 & سرفه & \\
\hline$r r / Q$ & sV & تنكَى نفس & \\
\hline TF & \&A & 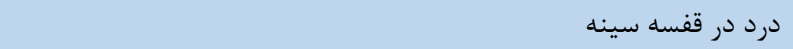 & \\
\hline 1. & $r \cdot$ & خلط خونى & علماتم \\
\hline$\wedge$ & 19 & 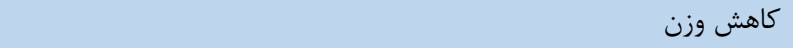 & \\
\hline $\mid r / \Delta$ & ra & ن امشخص & \\
\hline$F \Delta / \Delta$ & 91 & درد استخوان & \\
\hline$r \cdot 10$ & (1) & 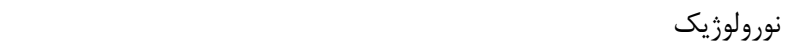 & \\
\hline $1 Y / \Delta$ & ra & شكم درد & علائم يارانئويلاستيك \\
\hline r & 4 & سندروم وريد اجوف فوقانى (SVC: Superior Vena Cava Syndrome) & \\
\hline $1 / 10$ & 19 & ساير & \\
\hline $1 / 0$ & r & I & \\
\hline ir & rq & II & \\
\hline $10 / \Delta$ & 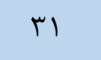 & III & مرحله بالينى \\
\hline$\Delta \Lambda / \Delta$ & $11 \mathrm{~V}$ & IV & \\
\hline $11 / 0$ & r & نامشخص & \\
\hline$F r / d$ & $\wedge \vee$ & استخوان & \\
\hline$r \cdot$ & f. & سيستم اعصاب مركزى & \\
\hline 9 & 11 & كبد & \\
\hline$\Delta$ & 1 . & يلور و ديافراگم & محل انتشار سرطان \\
\hline If & rA & بدون متاستاز & \\
\hline$r \cdot 10$ & (4) & نامشخص & \\
\hline 9 & 11 & ساير نقاط بدن & \\
\hline
\end{tabular}


كه مصرف سيگار با نوع پاتولوزى سرطان ريه ارتباط معنادارى

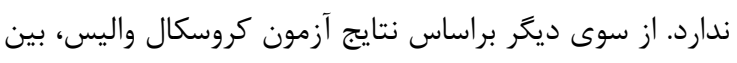

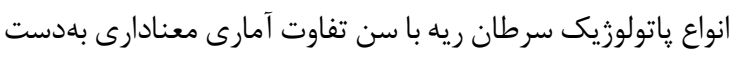

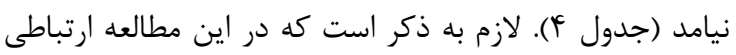

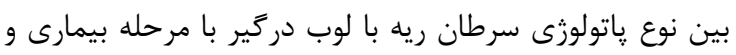
متاستاز مشاهده نخرديد.
(LUL)

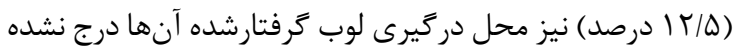

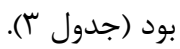
در ارتباط با توزيع نوع پاتولوزى سرطان ريه براساس جنس،

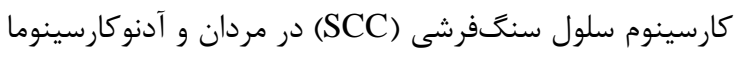

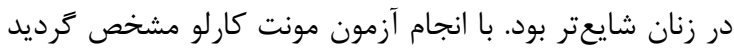

جدول ऍ: توزيع فراوانى سرطان ريه به تفكيك انواع پاتولوزيك و لوب درگير در سرطان

\begin{tabular}{|c|c|c|c|}
\hline درصد & فراوانى & & متغير \\
\hline ( ) & $9 V$ & سلول سنگَفرشى & \multirow{5}{*}{ نوع ياتولوزيك } \\
\hline ru & $\Delta \varphi$ & سلول كوجى & \\
\hline$r / / Q$ & fr & آدنوكارسينوما & \\
\hline v & if & ساير & \\
\hline 1 . & $r \cdot$ & نامشخص & \\
\hline$r V / Q$ & $\Delta \Delta$ & لوب فوقانى ريه راست & \multirow{7}{*}{ لوب دركير } \\
\hline$r m / Q$ & FV & لوب فوقانى ريه جٍ & \\
\hline if & rA & لوب تحتانى ريه راست & \\
\hline 11 & tr & لوب ميانى ريه راست & \\
\hline $9 / 0$ & 19 & لوب تحتانى ريه راست & \\
\hline r & f & منتشر، ساير & \\
\hline $1 T / \Delta$ & $r \Delta$ & نامشخص & \\
\hline
\end{tabular}

جدول f: فراوانى انواع پاتولوزيك سرطان ريه به تفكيك جنس، سن، سابقه مثبت فاميلى، سابقه مصرف سيخار و سابقه مصرف اوِيوئيد و قليان

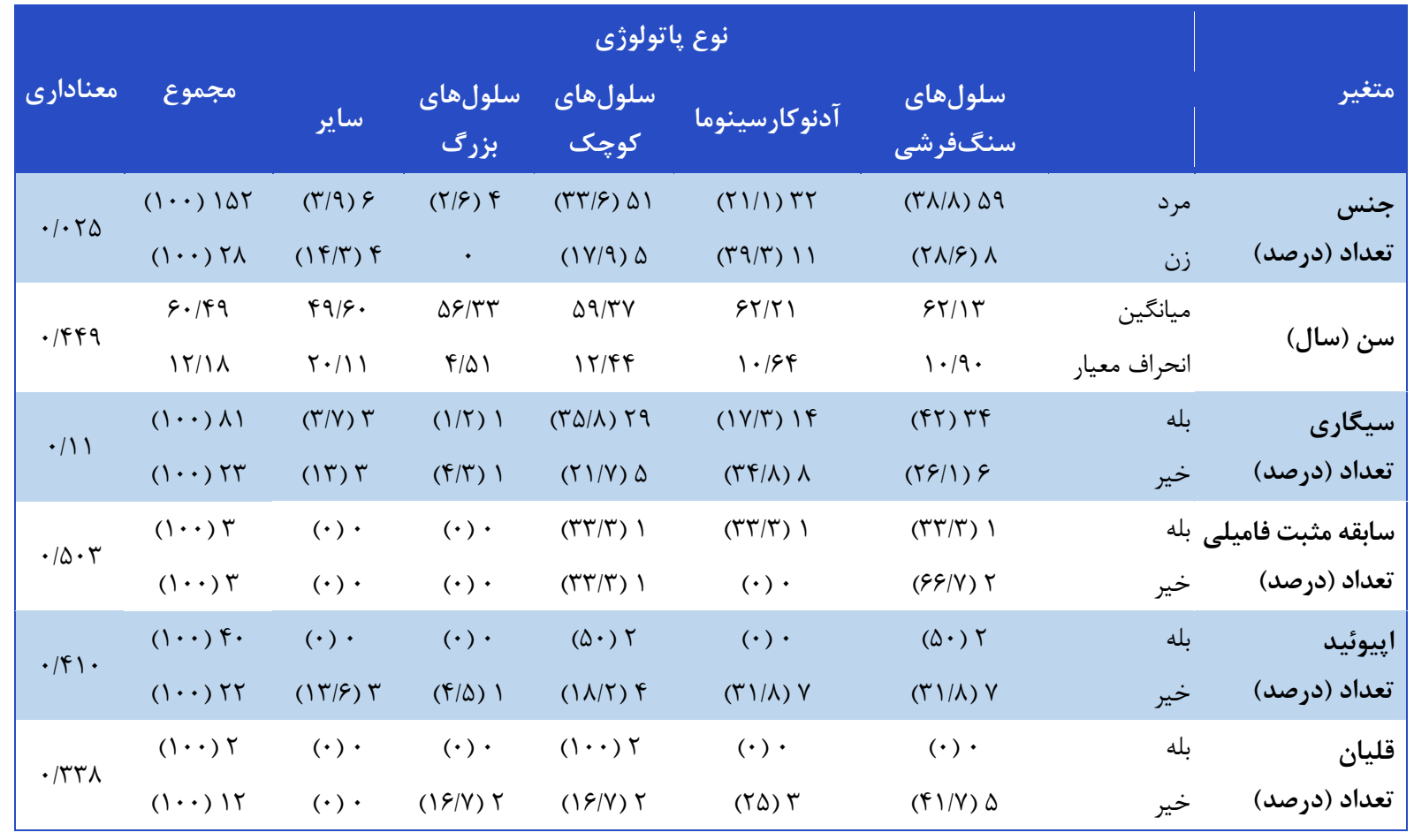

ييشرفتهاى تشخيصى و درمانى در درمان بيمارىها و ساير

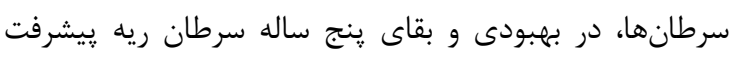

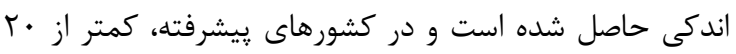

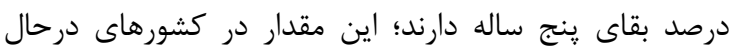

هدف از انجام مطالعه حاضر، بررسى إييدميولوزيك و

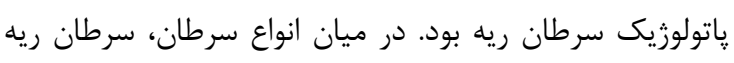

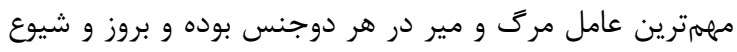

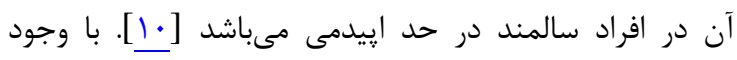


در مطالعه حاضر بيشتر بيماران مبتلا به سرطان ريه هنگًام

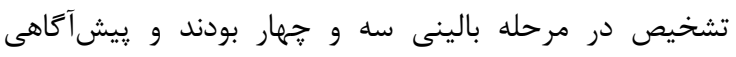

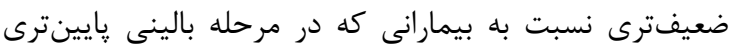

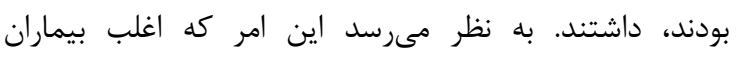

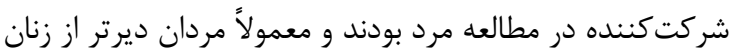

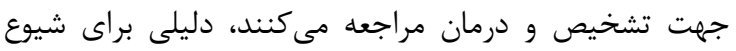
مرحله بالينى بالا در مطالعه حاضر باشد.

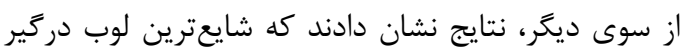

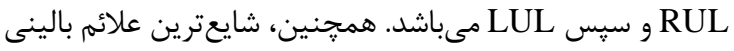

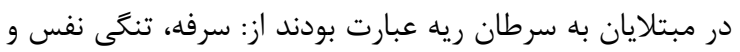

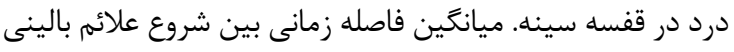
تا تشخيص نيز بس/ه ماه بود. علاوهبراين، شايعترين علائم

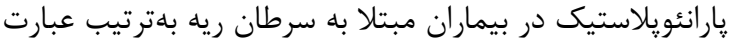

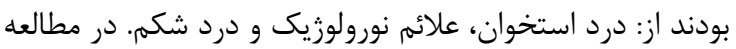
احتشامى افشار و همكاران نشان داده شد كه ميانگين سنى دورد

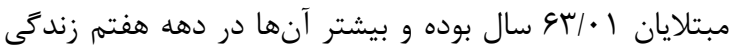

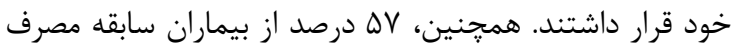

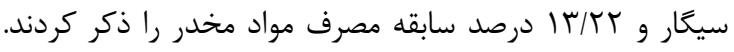
در زروهى كه از سيخار استفاده مىنمودند، شايعترين

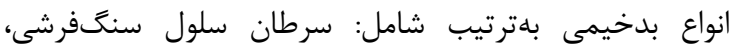

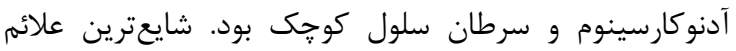
بالينى كه بيماران با آنها مراجعه كرده بودند نيز سرفه، تنكى سلى

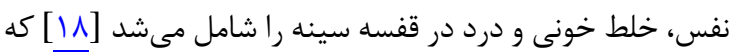
اين نتايج با يافتههاى مطالعه حاضر همخوانى دارد. لازم به ذذر درد

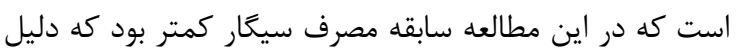

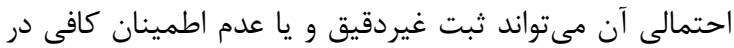

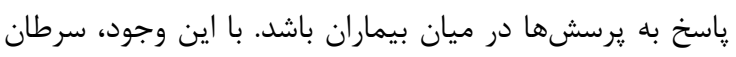

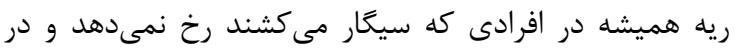

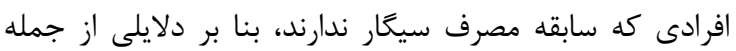

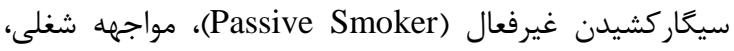

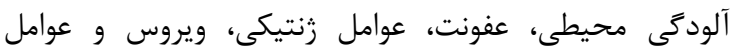

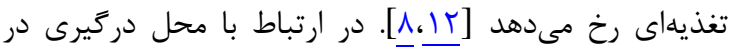

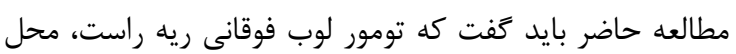
بيشترين دركيرى بود. در مطالعه قبادى و همكاران در اردبيل، بوديل

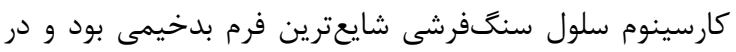

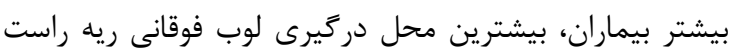

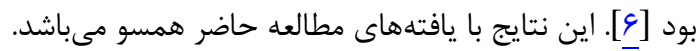

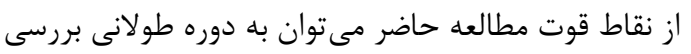

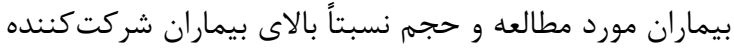

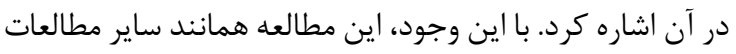

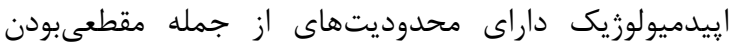

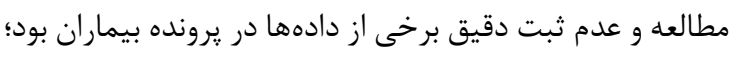

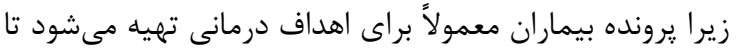

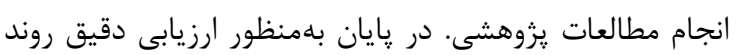

توسعه به بيش از • ا درصد نمىرسد [11]]. اطلاع از إيبدميولوزى إزى

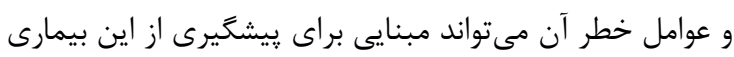

باشد.

نتايج مطالعه حاضر نشان دادند كه از نظر زمانى، روند

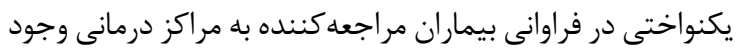

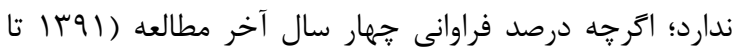

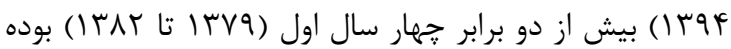

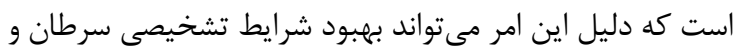

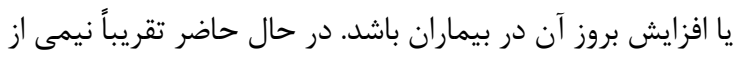

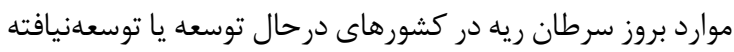

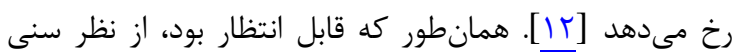

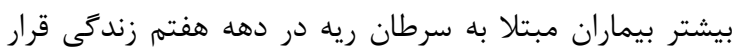
داشتند و ميانغين سنى افراد مبتلا تقريباً .9 سال بود. اصولاً بيمارى سرطان يك بيمارى مربوط به دوران سالمندى مىباشدي؛

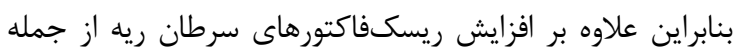

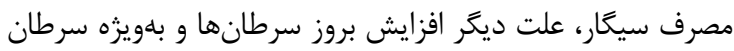

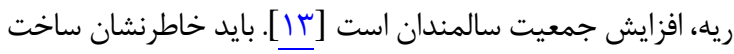

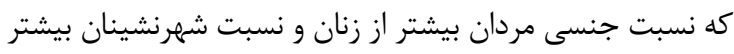

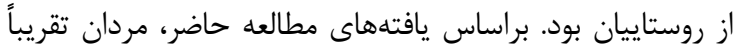

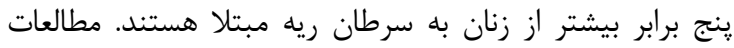

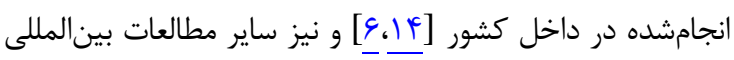
نيز نشان مىدهند كه خطر بروز سرطان ريه در مردان بيشتر از

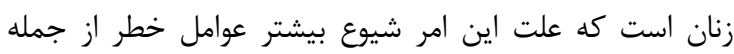

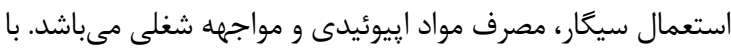

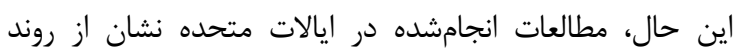

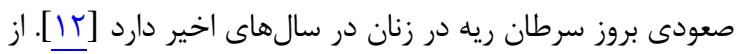

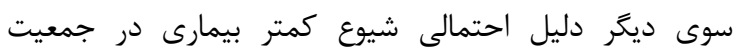

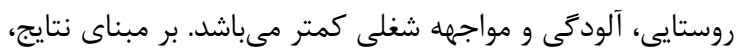

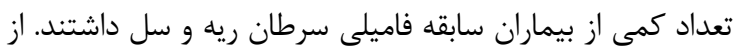
بين سيعار، قليان، مواد إييوئيدى و صنعتى نيز بالاترين اعتياد به به بهان

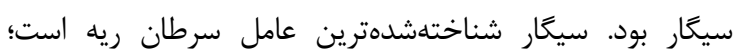

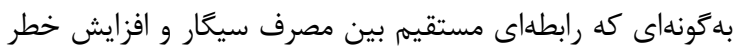

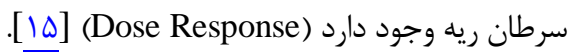

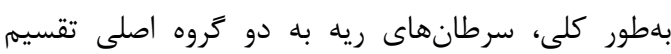

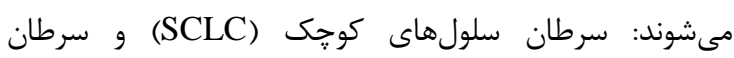

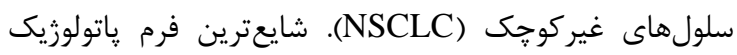

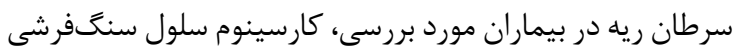

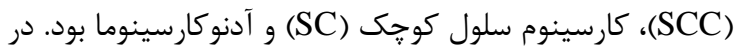
اين راستا، در مطالعه نجفى و همكاران نشان داده شد كه بيشتر

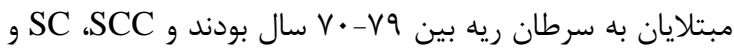

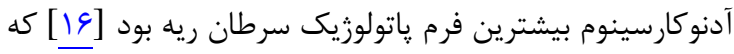

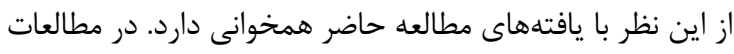
انجامشده در برخى از كشورهاى توسعهيافته، آدنوكارسينوم شايعترين فرم هيستولوزى مىباشد [IV] 


$$
\begin{aligned}
& \text { ديگر يايين بود. بر مبناى نتايج، ميانگين فاصله زمانى بين شروع }
\end{aligned}
$$

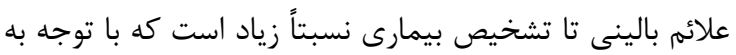

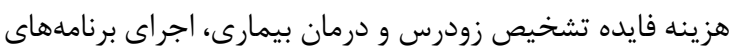

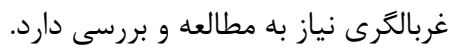$$
\text { تشكر و قلروانى }
$$

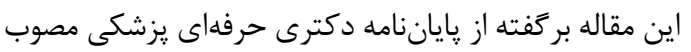

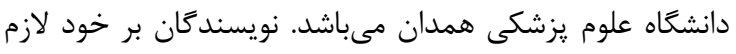

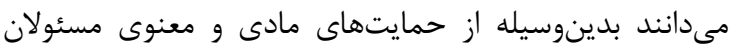

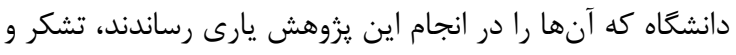

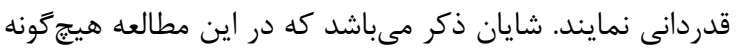$$
\text { تضاد منافعى از سوى نويسندگان كزارش نشده است. }
$$

\section{REFERENCES}

1. Siegel R, Ward E, Brawley O. Cancer statistics, 2011: the impact of eliminating socioeconomic and racial disparities on premature cancer deaths. CA Cancer J Clin. 2011;61(4):21236. PMID: 21685461 DOI: 10.3322/caac.20121

2. Jemal A, Bray F, Center MM, Ferlay J, Ward E, Forman D. Global cancer statistics. CA Cancer J Clin. 2011;61(2):6990. PMID: 21296855 DOI: $10.3322 /$ caac. 20107

3. International Early Lung Cancer Action Program Investigators, Henschke CI, Yankelevitz DF, Libby DM, Pasmantier MW, Smith JP, et al. Survival of patients with stage I lung cancer detected on CT screening. N Engl J Med. 2006;355(17):1763-71. PMID: 17065637 DOI: 10.1056/ NEJMoa060476

4. Didkowska J, Wojciechowska U, Mañczuk M, Łobaszewski J. Lung cancer epidemiology: contemporary and future challenges worldwide. Ann Transl Med. 2016;4(8): 150. PMID: 27195268 DOI: 10.21037/atm.2016.03.11

5. Brawley OW. Avoidable cancer deaths globally. CA Cancer J Clin. 2011;61(2):67-8. PMID: 21296854 DOI: 10.3322/caac. 20108

6. Ghobadi H, Sharghi A, Sadat-Kermani J. Epidemiology and risk factors for lung cancer in Ardabil, Iran. J Ardabil Univ Med Sci. 2013;13(2):220-8. [Persian]

7. Ferketich AK, Niland JC, Mamet R, Zornosa C, D'Amico TA, Ettinger DS, et al. Smoking status and survival in the national comprehensive cancer network non-small cell lung cancer cohort. Cancer. 2013;119(4):847-53. PMID: 23023590 DOI: 10.1002/cncr.27824

8. Minna J, Schiller JH. Harrison's principles of internal medicine. 17 ${ }^{\text {th }}$ ed. New York: McGraw-Hill; 2008.

9. Shroff GS, Viswanathan C, Carter BW, Benveniste MF, Truong MT, Sabloff BS. Staging lung cancer: metastasis. Radiol Clin North Am. 2018;56(3):411-8. PMID: 29622076 DOI: 10.1016/j.rcl.2018.01.009

$$
\begin{aligned}
& \text { بيمارى و وضعيت إييدميولوزيك آن، گرفتن شرح حال دقيق از }
\end{aligned}
$$

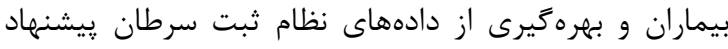

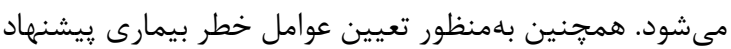

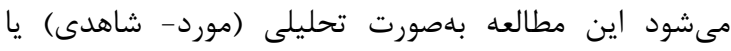

$$
\begin{aligned}
& \text { آيندهنغر تكرار كردد. }
\end{aligned}
$$

$$
\begin{aligned}
& \text { نتيجه كيرى } \\
& \text { شايعترين سن بروز سرطان ريه، دهه هفتم زندكى بوده و }
\end{aligned}
$$

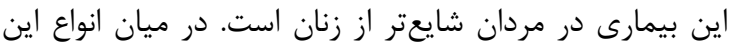

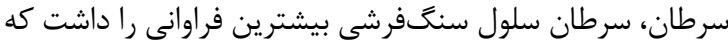

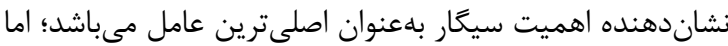

$$
\begin{aligned}
& \text { درصد فراوانى مصرف سيگار و مواد إييوئيدى نسبت به مطالعات }
\end{aligned}
$$

10. Chen WQ, Zuo TT, Zheng RS, Zeng HM, Zhang SW, He J. Lung cancer incidence and mortality in China in 2013. Zhonghua Zhong Liu Za Zhi. 2017;39(10):795-800. PMID: 29061027 DOI: 10.3760/cma.j.issn.0253-3766.2017.10.015

11. Radziszewska A, Karczmarek-Borowska B, GradalskaLampart M, Filip AA. Epidemiology, prevention and risk morbidity factors for lung cancer. Pol Merkur Lekarski. 2015;38(224):113-8. PMID: 25771522

12. Dela Cruz CS, Tanoue LT, Matthay RA. Lung cancer: epidemiology, etiology, and prevention. Clin Chest Med. 2011;32(4):605-44. PMID: 22054876 DOI: 10.1016/j.ccm. 2011.09.001

13. Kristeleit H, Enting D, Lai R. Basic science of lung cancer. Eur J Cance. 2011;47(Suppl 3):S19-21. PMID: 21943998 DOI: 10.1016/S0959-8049(11)70186-1

14. Almasi H, Farahmand M, Hassanzadeh J, Raei M. The trend of lung cancer incidence rate based on Fars province cancer registery data, 2001-2008. Payesh. 2012;11(4):477-83. [Persian]

15. Doll R, Hill AB. Smoking and carcinoma of the lung; preliminary report. Br Med J. 1950;2(4682):739-48. PMID: 14772469

16. Najafi F, Jafari R, Mozafari HR, Leghaei Z. Trend in lung cancer incidence in Kermanshah province-Iran. $J$ Kermanshah Univ Med Sci. 2011;14(4):342-348. [Persian]

17. Pallis AG, Syrigos KN. Lung cancer in never smokers: disease characteristics and risk factors. Crit Rev Oncol Hematol. 2013;88(3):494-503. PMID: 23921082 DOI: 10.1016/j.critrevonc.2013.06.011

18. Ehteshami Afshar A, Moosavi MA, Aram N, Deldar M, Raiisi S, Goharzad Ataie M, et al. Determination of frequency of histopathologic types of primary lung neoplasms in those patients admitted in tehran hospitals. Razi J Med Sci. 2002;8(26):373-9. [Persian] 